\title{
The Effects of Outsourcing and Offshoring of Independent Audit Procedures on Bank Loan Officers' Perceptions of Financial Statement Reliability and Loan Decisions
}

\author{
Lydia N. Didia \\ Pennsylvania State University-Harrisburg \\ Adrian L. Mayse \\ Howard University \\ Edward Charles Randle \\ Mississippi College
}

This paper examines whether outsourcing and offshoring of independent audit procedures affect bank loan officers' perceptions of financial statement reliability and loan decisions. A $2 \times 2$ between-subjects experimental design is utilized to investigate the main and interactive effects of outsourcing and offshoring of audit procedures. The results provide empirical evidence that sourcing (insourced or outsourced) or location (onshore or offshore) of independent audit procedures does not impact bank loan officers' perceptions and decisions. These implications are significant for accounting researchers, practitioners and policy setters.

\section{INTRODUCTION}

The use of outsourcing, especially offshore outsourcing, has sparked concerns by policymakers and the general public. There is a concern in the accounting profession about the impact of outsourcing and offshoring. PCAOB expressed concern that there is an increase in offshoring of audit procedures to relatively low-cost labor. These procedures are not known to users of financial statements (PCAOB, 2011). On the other hand, accounting firms are of the opinion that audit work that involves outsourcing and offshoring of audit procedures are of equivalent or higher quality compared to audit work not outsourced and offshore. However, studies show that people have negative perceptions concerning outsourcing especially offshoring (Blackman, Freedman, \& Levy, 2004; Brody, Coulter, \& Jewell, 2006; Daugherty, Dickins, \& Fennema, 2013; Downey, 2017; Lyubimov, Arnold, \& Sutton, 2013).

The first concern of offshoring is the local auditor's ability to accurately supervise audit work (i.e., distance increases affect perceptions of audit quality) (Blackman et al., 2004; Lyubimov et al., 2013; Mintz, 2004; Sunderland \& Trompeter, 2017). Lyubimov et al. (2013) found that jurors perceived work performed by another firm located outside the country to have the lowest quality and the highest risk. 
A second concern is a legal liability involving audit failure. Studies show that jurors award the highest damages in an audit failure when the work is completed in another country by the auditor of another firm (Daugherty et al., 2013; Lyubimov et al., 2013). Daugherty et al. (2013) find that jurors assessed a higher damage for work offshore to India compared to work performed in the U.S. despite the level of judgment involved. Also, Lyubimov et al. (2013) find that jurors assessed higher damages as the audit procedures move further away from the primary auditor.

A third concern is the issue of work design amongst the principal auditors and the other auditors. Downey (2017) points out that local auditors have an issue with trusting offshore auditors. Most of the audit work outsourced and offshore from the U.S. and other North American countries occurs in India (Daugherty \& Dickins, 2009; Whitehouse, 2009). The distance between the auditors seems to exacerbate the lack of trust. Constant communication and face-to-face interactions foster trust amongst employees (Polzer, Crisp, Jarvenpaa, \& Kim, 2006). The local auditors and the other auditors are in different geographical locations, hence making it difficult for the development of trust. The auditors interviewed by Downey (2017) view the work conducted by offshore auditors as substandard, therefore redoing the job received from the offshore auditors. The study further shows that task identity is affected negatively, especially for work not deemed significant.

The Big Four audit firms currently offshore between five and twenty percent of their audit procedures and this is expected to steadily increase (Daugherty \& Dickins, 2009; Downey, 2017; Hanes, 2013). Given the inevitable trend of offshoring and outsourcing, we question how this will impact third parties' perceptions of an audit client. The auditor audits the financial statement, but third parties rely on the auditor's report to make decisions about the audit clients.

The reliance of bank loan officers on the auditor's reports for decision making concerning their clients makes the issue of outsourcing and offshoring of concern to this audience. This paper examines whether outsourcing and offshoring of independent audit procedures affect bank loan officers' perceptions of financial statement reliability and loan decisions.

Similar to Lyubimov et al. (2013), we use a 2 × 2 between-subjects experimental design to investigate the main and interactive effects of outsourcing and offshoring of independent audit procedures. We manipulate sourcing (insourced to another office of their firm or outsourced to a separate firm) and location of work performed (onshore or offshore). Contrary to our predictions, the results indicate that outsourcing and offshoring of audit procedures do not significantly affect bank loan officers' perceptions of financial statement reliability and loan decisions.

In light with the recent development with PCAOB, where Firms will be required to disclose information about certain participants that performed an audit (PCAOB, 2017), this study provides information on how this disclosure will affect financial statement users. This study is important to audit practice because it examines bank loan officers' perceptions of outsourcing and offshoring audit procedures. This study is also important for practitioners, managers and audit committees as they worry about the potential effect of outsourcing and offshoring audit procedures. Chan and Moser (2014) conducted an experiment in which they investigated the CFO and controller's perceptions of offshoring. The result of their study indicates that the participants in that study are willing to embrace lower audit fees associated with offshoring; however, they are concerned about how investors and other stakeholders will react to these procedures.

In the next section, we provide the background and hypotheses development. Next, we discuss the research methodology. Then, we present the results and implications of the study. Lastly, we provide conclusions, limitations and future research.

\section{BACKGROUND AND HYPOTHESES DEVELOPMENT}

As early adopters, manufacturing industries have continually used outsourcing and offshoring as part of a cost reduction strategy. In the 1980s, the service industry began using outsourcing and offshoring for services such as payroll, accounting, financial and legal research (Lyubimov et al., 2013; Massini \& Miozzo, 2012). The continuous improvement in technology and global communication triggered the 
expanded use of outsourcing and offshoring by service industry (Blinder, 2006). Additional factors that triggered the expanded use of offshoring include the concern over a declining pool of available talent in the highly developed countries and significant and favorable cost structure differences (Daugherty et al. 2012).

Even though studies may use outsourcing and offshoring interchangeability, there is a difference. Outsourcing involves companies deciding to relinquish the authority to perform some or all of their business activities to an outside organization. Offshoring consists of a decision to have some or all of the business activities conducted in another country (Bunyaratavej, Doh, Hahn, Lewin, \& Massini, 2011; Grappi, Romani, \& Bagozzi, 2013; Robertson, Lamin, \& Livanis, 2010). Daugherty et al. ( 2013, 56) define offshoring as the "process of using unaffiliated foreign companies or affiliated foreign companies (AOEs) to manufacture goods or perform services." Offshoring of domestic audit procedures is different from the traditional referral of audit work to overseas affiliates. In the traditional referral of audit work to overseas affiliates, the foreign auditors are engaged to perform audit procedures on foreign subsidiaries, while offshoring of audit procedures involves transferring performance of certain audit procedures on the domestic records of U.S.-based clients to auditors located in another country (Daugherty \& Dickins, 2009; Hanes, 2013).

The benefits associated with outsourcing include reduced cost and the ability of employees to focus on core activities. Additional benefits related to offshoring include the ability to work around the clock due to time zone differences, the ability for the local employees to focus on the more advanced work. The increased competition among public accounting firms and the merger activity of the 1980s and 1990s have led to stagnation of audit revenues (Swanger \& Chewning, 2001). Furthermore, Lowe et al. (1999) noted that globalization and overcapacity have also contributed to accounting firms seeking cost reduction strategies. Therefore accounting firms have employed the benefits of outsourcing and offshoring. Daugherty et al. (2012) note that the volume of offshore operations is substantial and is expected to increase. While accounting firms have primarily outsourced and offshored tax preparation, they are increasingly outsourcing and offshoring independent audit procedures. Daugherty et al. (2012) further note that the growth may be more for audit task given the steady decrease of audit fees since 2007 . In 2013, more than two million jobs were outsourced, with many of those opportunities going to workers in China and India (Selvaggio, 2014). Big Four audit firms offshore between five and twenty percent of their audit procedures (Daugherty \& Dickins, 2009; Downey, 2017; Hanes, 2013).

The use of outsourcing especially offshore outsourcing has sparked concerns by policymakers and the general public. Dutta and Roy (2005) note that offshoring has triggered economic debate on free market and globalization. While some are in favor of offshoring others are not. The public has reacted negatively to offshoring of jobs because they perceive the process to have caused loss of employment. Thirty-five states have proposed laws that prevent the flow of state funds to companies that do work overseas using their firms established in foreign countries or through subcontractors. The 2004 Federal budget had provisions that prohibit the federal government from awarding certain contracts to companies that have moved their work overseas (Daugherty \& Dickins, 2009; Gião, Oliveira Junior, \& Gondim de Vasconcellos, 2008). Garner (2004) finds that though offshoring service jobs put stress on U.S. jobs, it should not, in the long run, reduce U.S employment or production.

Though the accounting firms are of the opinion that audit work outsourced or offshored may be of the same or even higher quality compared to the work not involving these procedures (Daugherty \& Dickins, 2009), there are concerns in the accounting profession about the impact of outsourcing and offshoring. The concerns are: 1) the reputation of the audit profession (Brody et al., 2006; Mintz, 2004; Robertson \& Stone, 2005), 2) the capability to accurately plan and supervise work (Blackman et al., 2004; Lyubimov et al., 2013; Mintz, 2004; Sunderland \& Trompeter, 2017), 3) the perceived quality of work conducted (Daugherty \& Dickins, 2009; Shamis, Green, Sorensen, \& Kyle, 2005), 4) the reaction on audit failure involving lawsuit (Brody et al., 2006; Daugherty \& Dickins, 2009; Lyubimov et al., 2013), and 5) the issue of work design and trust (Downey, 2017).

Lyubimov et al. (2013) examined the legal liability associated with outsourcing and offshoring of audit task. The jurors in that study perceive the work offshored to another firm to have the least quality 
and the highest risk. This study extends the work on outsourcing and offshoring by examining the impact of outsourcing and offshoring on bank loan officers' perceptions of financial statement reliability and loan decisions.

Studies show that geographic proximity affects reliance and decision making. For instance, Baik et al. (2010) find that stock held or traded by local institutional investors earn higher excess returns around future earnings announcement compared to non- local institutional investors. Malloy (2005) finds that geographic proximity affects the forecasting decisions of analysts. Also, Kedia and Rajgopal (2011) show that firms located closer to SEC regional office are less likely to be involved in misconduct. Also, Choi et al. (2012) show that auditor-client geographic proximity affects audit quality positively. The studies mentioned above show that geographic proximity enhances monitoring and supervision. Roth and O'Donnell (1996) note that as cultural distance increases, it becomes more difficult and expensive for headquarters to obtain accurate and complete information from subsidiaries. Thus leading to the following hypotheses:

H1: $\quad$ Outsourcing of audit procedures will negatively impact bank loan officers' perceptions of audit client financial statement reliability.

$\mathrm{H} 2$ : $\quad$ Having the audit procedures performed in another country will negatively impact bank loan officers' perceptions of audit client financial statement reliability.

H3: $\quad$ Outsourcing of audit procedures will negatively impact bank loan officers' loan decision to an audit client.

H4: Having the audit procedures performed in another country (offshored) will negatively impact bank loan officers' loan decision to an audit client.

H5: Outsourcing of audit procedures to an audit firm in another country (offshored) will negatively impact bank loan officers' perceptions of audit client financial statement reliability.

H6: Outsourcing of audit procedures to an audit firm in another country (offshored) will negatively impact bank loan officers' loan decision to an audit client.

\section{RESEARCH METHODOLOGY}

This study employs a $2 \times 2$ between-subjects experimental design to investigate whether outsourcing and offshoring of audit procedures affect bank loan officers' perceptions of financial statement reliability and loan decisions. The following subsections detail the experimental case, participants, independent variables, and dependent variables.

\section{Experimental Case}

First, participants (bank loan officers) are asked to access the survey website and authorize the necessary consent form. Next, they are presented with the experimental case which consists of background information (adapted from Lyubimov et al. 2013) and selected audited financial statements (adapted from Schneider \& Church 2008) about a fictitious company called Chad Widget Company. Chad Widget Company is a publicly traded company and is an audit client of Zodak CPA firm, a large international accounting firm. Chad Widget Company is seeking a $\$ 5$ million line of credit to expand its business. The line of credit would be secured by the company's accounts receivable. Zodak CPA firm performed the 2014 audit of Chad Widget Company. Zodak CPA firm rendered an unqualified opinion on both the financial statements and on internal control over financial reporting. The bank loan officers are informed that Zodak CPA firm disclosed that they used their local office personnel to complete the majority of the work, but also engaged another party to assist with certain revenue audit procedures. Zodak CPA firm is responsible for the audit work performed by the third party auditor and thus have properly supervised their work by PCAOB standards. After the case, the participants are asked to respond to questions on their perceptions of financial statement reliability, and loan decision. Next, participants answer the manipulation check questions followed by demographic and additional questions. 
The instrument used in this study was pretested with eight bank loan officers located in one of the southern states in the U.S. and through interaction with graduate students in one of the state universities located in the southern part of the USA.

\section{Participants}

Bank loan officers are the participants in this study because they are sophisticated users of financial statements. Bank loan officers' sophistication adds to the external validity of this study in that the result can be generalized to other sophisticated users such as financial analysts. Schneider and Church ( 2008) state that bank loan officers are suitable for studies involving loan decisions because they frequently analyze financial statement information. Also, bank loan officers play an essential role in the debt market given that over 50 percent of the loans in the debt market are issued by banks (Li, Qiu, \& Wan, 2011). The participants are recruited using Qualtrics, a web-based company that works with industry partners to build both broad and targeted participant panels (Brandon, Long, Loraas, Mueller-Phillips, \& Vansant, 2014).

Out of the 274 participants considered eligible for the study, 113 (41.24 percent) failed one or two of the manipulation checks. A manipulation check was performed to ensure that participants understood the experimental case by asking them to indicate whether the audit procedures were outsourced and offshored. The manipulation failure rate is comparable to prior research on electronic administered surveys and experiments (Andrews, Nonnecke, \& Preece, 2003; Brown-Liburd \& Zamora, 2015; Oppenheimer, Meyvis, \& Davidenko, 2009). Hence, these participants were eliminated from the study.

Additionally, ten additional participants were eliminated from the study due to incomplete responses, leaving 151 complete and usable responses. Table 1 shows the demographic information of the 151 participants. As shown in Table 1, the participants are evenly distributed among the four groups. ChiSquare test shows that significant difference exists between the groups relating to bank assets size. The analysis of covariance (ANCOVA) examines bank asset size as a covariate, and the results do not change.

The demographic statistics in Table 1 show that sixty-five percent of the participants have at least five years of lending experience and seventy-eight percent hold at least a bachelor's degree. Eighty-seven percent of the participants have a current title of bank loan officer or higher, and approximately threefourths of the participants ( 74 percent) devote fifty percent or more of their time to loan approval. About seventeen percent of the participants have a professional certification. A substantial majority of the participants ( 83 percent) are with banks that have assets are one hundred million or higher. Also, ninetytwo percent of the participants report they are either somewhat knowledgeable or very knowledgeable of auditing.

Seventy-five percent report they are somewhat knowledgeable or very knowledgeable about outsourcing audit procedures while sixty-two percent report they are either somewhat knowledgeable or very knowledgeable about offshoring audit procedures. Sixty-five percent of the participants are thirty-six years old or older with fifty-four percent male and forty-six percent female. The demographic statistics show that most of the participants in this study have many years of lending experience, knowledgeable of auditing, and knowledge of outsourcing and offshoring of audit procedures. The participants' demographics provide credence to the validity of the study. 
TABLE 1

PARTICIPANTS' DEMOGRAPHIC INFORMATION

\begin{tabular}{|c|c|c|c|c|c|c|}
\hline & $\frac{\text { Insource }}{\text { Onshore }}$ & $\frac{\text { Insource }}{\text { Offshore }}$ & $\frac{\text { Outsource }}{\text { Onshore }}$ & $\frac{\text { Outsource }}{\text { Offshore }}$ & $\begin{array}{l}\text { Total } \\
\text { Count }\end{array}$ & $\begin{array}{c}\text { Total } \\
\text { Percent }\end{array}$ \\
\hline Group Size & 40 & 32 & 41 & 38 & $\overline{151}$ & $100 \%$ \\
\hline \multicolumn{7}{|l|}{ Loan Experience } \\
\hline $1-4$ years & $30 \%$ & $44 \%$ & $32 \%$ & $34 \%$ & 52 & $35 \%$ \\
\hline $5-10$ years & $35 \%$ & $22 \%$ & $41 \%$ & $37 \%$ & 52 & $35 \%$ \\
\hline $11-15$ years & $13 \%$ & $9 \%$ & $10 \%$ & $5 \%$ & 14 & $9 \%$ \\
\hline \multirow{2}{*}{ Over 15 years } & $\underline{22 \%}$ & $\underline{25 \%}$ & $\underline{17 \%}$ & $\underline{24 \%}$ & $\underline{33}$ & $\underline{21 \%}$ \\
\hline & $\overline{100 \%}$ & $\overline{100 \%}$ & $\overline{100 \%}$ & $\overline{100 \%}$ & $\overline{151}$ & $\overline{100 \%}$ \\
\hline \multicolumn{7}{|l|}{ Highest Degree Earned } \\
\hline High School Diploma & $3 \%$ & $19 \%$ & $7 \%$ & $10 \%$ & 14 & $9 \%$ \\
\hline Associate Degree & $11 \%$ & $3 \%$ & $12 \%$ & $21 \%$ & 19 & $13 \%$ \\
\hline Bachelor's Degree & $53 \%$ & $50 \%$ & $42 \%$ & $40 \%$ & 69 & $46 \%$ \\
\hline \multirow[t]{2}{*}{ Master's Degree and above } & $\underline{33 \%}$ & $\underline{28 \%}$ & $\underline{39 \%}$ & $\underline{29 \%}$ & $\underline{49}$ & $\underline{32 \%}$ \\
\hline & $100 \%$ & $100 \%$ & $100 \%$ & $100 \%$ & 151 & $100 \%$ \\
\hline \multicolumn{7}{|l|}{$\begin{array}{l}\text { Percentage of Time } \\
\text { Devoted to Loan }\end{array}$} \\
\hline Below 50\% & $30 \%$ & $34 \%$ & $15 \%$ & $26 \%$ & 39 & $26 \%$ \\
\hline $50-69 \%$ & $34 \%$ & $19 \%$ & $24 \%$ & $37 \%$ & 44 & $29 \%$ \\
\hline $70-79 \%$ & $20 \%$ & $15 \%$ & $32 \%$ & $8 \%$ & 29 & $19 \%$ \\
\hline $80-89 \%$ & $8 \%$ & $13 \%$ & $22 \%$ & $18 \%$ & 23 & $15 \%$ \\
\hline \multirow[t]{2}{*}{ Over $90 \%$} & $\underline{8 \%}$ & $19 \%$ & $7 \%$ & $11 \%$ & $\underline{16}$ & $11 \%$ \\
\hline & $100 \%$ & $\overline{100 \%}$ & $100 \%$ & $\overline{100 \%}$ & $\overline{151}$ & $\overline{100 \%}$ \\
\hline \multicolumn{7}{|l|}{ Title } \\
\hline Credit Analyst & $8 \%$ & $19 \%$ & $10 \%$ & $16 \%$ & 19 & $12.6 \%$ \\
\hline Loan officer & $60 \%$ & $44 \%$ & $56 \%$ & $61 \%$ & 84 & $55.6 \%$ \\
\hline Vice President & $22 \%$ & $22 \%$ & $22 \%$ & $8 \%$ & 28 & $18.5 \%$ \\
\hline President/CEO & $0 \%$ & $0 \%$ & $5 \%$ & $5 \%$ & 4 & $2.6 \%$ \\
\hline \multirow[t]{2}{*}{ Other } & $\underline{10 \%}$ & $\underline{15 \%}$ & $\underline{7 \%}$ & $\underline{10 \%}$ & $\underline{16}$ & $\underline{10.7 \%}$ \\
\hline & $100 \%$ & $100 \%$ & $100 \%$ & $100 \%$ & $\overline{151}$ & $100 \%$ \\
\hline
\end{tabular}

110 Journal of Accounting and Finance Vol. 18(3) 2018 


\section{TABLE 1 (CONTINUED) \\ DEMOGRAPHIC INFORMATION FOR PARTICIPANTS}

\begin{tabular}{|c|c|c|c|c|c|c|}
\hline & $\frac{\text { Insource }}{\text { Onshore }}$ & $\frac{\text { Insource }}{\text { Offshore }}$ & $\frac{\text { Outsource }}{\text { Onshore }}$ & $\frac{\text { Outsourc }}{\underline{\mathbf{e}}}$ & $\begin{array}{l}\text { Total } \\
\text { Coun }\end{array}$ & $\begin{array}{c}\text { Total } \\
\text { Percent }\end{array}$ \\
\hline Group Size & 40 & 32 & 41 & $\frac{\text { Offshore }}{38}$ & $\frac{\mathbf{t}}{151}$ & $100 \%$ \\
\hline \multicolumn{7}{|l|}{ Certification } \\
\hline Yes & $18 \%$ & $9 \%$ & $17 \%$ & $21 \%$ & 25 & $16.6 \%$ \\
\hline \multirow[t]{2}{*}{ No } & $82 \%$ & $91 \%$ & $83 \%$ & $79 \%$ & 126 & $83.4 \%$ \\
\hline & $\overline{100 \%}$ & $\overline{100 \%}$ & $\overline{100 \%}$ & $\overline{100 \%}$ & $\overline{151}$ & $\overline{100 \%}$ \\
\hline \multicolumn{7}{|l|}{ Bank Asset Size } \\
\hline Less than $\$ 100$ million & $12 \%$ & $6 \%$ & $12 \%$ & $34 \%$ & 25 & $16.6 \%$ \\
\hline$\$ 100$ million - $\$ 1$ billion & $35 \%$ & $40 \%$ & $37 \%$ & $40 \%$ & 57 & $37.7 \%$ \\
\hline Over $\$ 1$ billion - $\$ 10$ billion & $33 \%$ & $38 \%$ & $29 \%$ & $16 \%$ & 43 & $28.5 \%$ \\
\hline \multirow[t]{2}{*}{ Over $\$ 10$ billion } & $20 \%$ & $16 \%$ & $22 \%$ & $10 \%$ & $\underline{26}$ & $17.2 \%$ \\
\hline & $100 \%$ & $\overline{100 \%}$ & $100 \%$ & $100 \%$ & 151 & $100 \%$ \\
\hline \multicolumn{7}{|l|}{ Knowledge of Auditing } \\
\hline Not at all Knowledgeable & $3 \%$ & $9 \%$ & $12 \%$ & $8 \%$ & 12 & $8 \%$ \\
\hline Somewhat Knowledgeable & $70 \%$ & $75 \%$ & $59 \%$ & $63 \%$ & 100 & $66 \%$ \\
\hline \multirow[t]{2}{*}{ Very Knowledgeable } & $\underline{27 \%}$ & $\underline{16 \%}$ & $\underline{29 \%}$ & $\underline{29 \%}$ & $\underline{39}$ & $\underline{26 \%}$ \\
\hline & $\overline{100 \%}$ & $\overline{100 \%}$ & $\overline{100 \%}$ & $\overline{100 \%}$ & $\overline{151}$ & $\overline{100 \%}$ \\
\hline \multicolumn{7}{|l|}{ Knowledge of Outsourcing } \\
\hline Not at all Knowledgeable & $28 \%$ & $25 \%$ & $34 \%$ & $11 \%$ & 37 & $25 \%$ \\
\hline Somewhat Knowledgeable & $55 \%$ & $59 \%$ & $44 \%$ & $68 \%$ & 85 & $56 \%$ \\
\hline \multirow[t]{2}{*}{ Very Knowledgeable } & $17 \%$ & $16 \%$ & $22 \%$ & $21 \%$ & $\underline{29}$ & $19 \%$ \\
\hline & $\overline{100 \%}$ & $\overline{100 \%}$ & $\overline{100 \%}$ & $\overline{100 \%}$ & $\overline{151}$ & $\overline{100 \%}$ \\
\hline \multicolumn{7}{|l|}{ Knowledge of Offshoring } \\
\hline Not at all Knowledgeable & $40 \%$ & $41 \%$ & $44 \%$ & $29 \%$ & 58 & $38 \%$ \\
\hline Somewhat Knowledgeable & $40 \%$ & $41 \%$ & $42 \%$ & $50 \%$ & 65 & $43 \%$ \\
\hline \multirow[t]{2}{*}{ Very Knowledgeable } & $\underline{20 \%}$ & $\underline{18 \%}$ & $\underline{14 \%}$ & $\underline{21 \%}$ & $\underline{28}$ & $\underline{19 \%}$ \\
\hline & $100 \%$ & $\overline{100 \%}$ & $\overline{100 \%}$ & $100 \%$ & 151 & $\overline{100 \%}$ \\
\hline \multicolumn{7}{|l|}{ Age } \\
\hline Under 26 & $5 \%$ & $3 \%$ & $5 \%$ & $8 \%$ & 8 & $5 \%$ \\
\hline $26-35$ & $30 \%$ & $34 \%$ & $27 \%$ & $29 \%$ & 45 & $30 \%$ \\
\hline $36-45$ & $28 \%$ & $19 \%$ & $34 \%$ & $13 \%$ & 36 & $24 \%$ \\
\hline $46-55$ & $17 \%$ & $31 \%$ & $17 \%$ & $26 \%$ & 34 & $23 \%$ \\
\hline \multirow[t]{2}{*}{ Over 55} & $\underline{20 \%}$ & $\underline{13 \%}$ & $\underline{17 \%}$ & $\underline{24 \%}$ & $\underline{28}$ & $\underline{19 \%}$ \\
\hline & $\overline{100 \%}$ & $\overline{100 \%}$ & $\overline{100 \%}$ & $\overline{100 \%}$ & $\overline{151}$ & $\overline{100 \%}$ \\
\hline \multicolumn{7}{|l|}{ Gender } \\
\hline Male & $55 \%$ & $53 \%$ & $61 \%$ & $45 \%$ & 81 & $54 \%$ \\
\hline \multirow[t]{2}{*}{ Female } & $\underline{45 \%}$ & $\underline{47 \%}$ & $\underline{39 \%}$ & $\underline{55 \%}$ & $\underline{70}$ & $\underline{46 \%}$ \\
\hline & $\overline{100 \%}$ & $\overline{100 \%}$ & $\overline{100 \%}$ & $\overline{100 \%}$ & $\overline{151}$ & $100 \%$ \\
\hline
\end{tabular}

\section{Independent Variables}

Similar to Lyubimov et al. 2013, the independent variables are 1) sourcing and 2) location. Sourcing is manipulated on two levels: insourcing and outsourcing. The independent variable, location is manipulated on two levels: onshore and offshore. Using a $2 \times 2$ between-subjects experimental design, the four experimental groups are: 1) another office of their firm located in Texas (onshore-insourcing), 2) 
another office of their own firm located in India (offshore-insourcing), 3) another accounting firm located in Texas (onshore-outsourcing), and 4) another accounting firm located in India (offshore-outsourcing).

\section{Dependent Variables}

There are two dependent variables in this study. The first dependent variable is financial statement reliability. This variable assesses bank loan officers' level of confidence in the accuracy and reliability of the client's audited financial statements. Similar to Lowe et al. (1999), two questions are asked to assess bank loan officers' perceptions of this variable. First, participants are asked to indicate their confidence that the audited financial statements are free from unintentional misstatements or omission. Second, the participants are asked to indicate their confidence that the audited financial statements are free from intentional misstatements or omission. The participants indicate their confidence on an 11-point Likert scale anchored on 0 (No Confidence) to 10 (Extreme Confidence). Prior studies use intentional misstatement and unintentional misstatements in assessing participants perceptions on different variables (e.g., Smith 2012; Foster et al. 2013).

The second dependent variable focuses on loan decisions. Two questions are utilized to assess the bank loan officers' decisions. Similar to Lowe et al. (1999), the first question is dichotomous and requires bank loan officers to make either an "approve" or "reject" recommendation on the loan application. The question is "What recommendation would you make on the loan application? The second question assesses the probability of the participants extending the line of credit at a reasonable interest rate assuming their company does not restrict the amount of loan extended to clients. The question is "What is the probability that you would extend $\$ 5,000,000$ line of credit to Chad Widget Company at a reasonable interest rate?" The participants assess the probability on a $0 \%$ to $100 \%$ scale.

\section{RESULTS AND IMPLICATIONS}

An analysis of variance (ANOVA) is conducted to explore the impact of sourcing and location on financial statement reliability. Table 2 and Table 3 show the main effect and interaction of the independent variables (sourcing and location) on bank loan officers' perceptions of financial statement reliability. Panel A of Table 2 shows the ANOVA results of perceptions of financial statement reliability (intentional material misstatement) as the dependent variable and Panel B reports the mean, standard deviation (SD) and the number (n) of participants in each experimental group. As indicated in panel A of Table 2, the main effect for sourcing is not statistically significant $\left(\mathrm{F}_{(1,147)}=1.646, \mathrm{p}=.202\right.$ one-tailed), the main effect for location is not statistically significant $\left(\mathrm{F}_{(1,147)}=.167\right.$ and $\mathrm{p}=.683$ one-tailed $)$ and also the interaction between sourcing and location is not statistically significant $\left.\left(\mathrm{F}_{(1,147}\right)=.091, \mathrm{p}=.763\right)$.

Panel A of Table 3 shows the ANOVA results of perceptions of financial statement reliability (unintentional material misstatement) as the dependent variable. Panel B of Table 3 shows the mean, standard deviation (SD) and number (n) of participants in each cell. As indicated in Panel A of Table 3, sourcing $\left(\mathrm{F}_{(1,147)}=.379, \mathrm{p}=.539\right.$ one-tailed $)$, and location $\left(\mathrm{F}_{(1,147)}=.002, \mathrm{p}=.963\right.$ one-tailed $)$ are not statistically significant. Interaction of sourcing and location $\left(\mathrm{F}_{(1,147)}=.203, \mathrm{p}=.653\right)$ is also not statistically significant. The results from Table 2 and 3 suggest that bank loan officers' perceptions of financial statement reliability do not differ across the treatment groups. 
TABLE 2

EFFECTS OF SOURCING AND LOCATION ON PERCEPTIONS OF FINANCIAL STATEMENT RELIABILITY -INTENTIONAL MATERIAL MISSTATEMENTA

Panel A: Analysis of Variance for Perceptions of Financial Statement ReliabilityIntentional Material Misstatement

\begin{tabular}{|c|c|c|c|c|c|c|}
\hline \multicolumn{2}{|l|}{ Source } & $\begin{array}{r}\text { Sum of } \\
\text { Squares }\end{array}$ & \multicolumn{2}{|r|}{ Mean } & $\mathrm{F}$ & $\operatorname{Sig}^{\mathrm{b}}$. \\
\hline$\overline{\text { Sourcing }}$ & & 6.877 & $\overline{1}$ & 6.877 & 1.646 & .202 \\
\hline Location & & .699 & 1 & .699 & .167 & .683 \\
\hline Sourcing * & & .380 & 1 & .380 & .091 & .763 \\
\hline Error & & 614.218 & 147 & 4.178 & & \\
\hline \multicolumn{7}{|c|}{$\begin{array}{l}\text { Panel B: Descriptive Statistic (Mean, Standard Deviation, and n) for Reliability -Intentional } \\
\text { Material Misstatement }\end{array}$} \\
\hline \multirow{3}{*}{ Insource } & & Onshore & & ffshore & \multicolumn{2}{|c|}{ Total } \\
\hline & Mean & 6.5 & & 6.31 & \multicolumn{2}{|c|}{6.44} \\
\hline & SD & 1.93 & & 2.05 & \multicolumn{2}{|c|}{1.98} \\
\hline & $\mathrm{n}$ & 40 & & 32 & \multicolumn{2}{|c|}{72} \\
\hline \multirow{3}{*}{ Outsource } & Mean & 6.88 & & 6.84 & \multicolumn{2}{|c|}{6.86} \\
\hline & $\mathrm{SD}$ & 2.12 & & 2.06 & \multicolumn{2}{|c|}{2.08} \\
\hline & $\mathrm{n}$ & 41 & & 38 & \multicolumn{2}{|c|}{79} \\
\hline \multirow[t]{3}{*}{ Total } & Mean & 6.72 & & 6.60 & \multicolumn{2}{|c|}{6.66} \\
\hline & $\mathrm{SD}$ & 2.03 & & 2.06 & \multicolumn{2}{|c|}{2.04} \\
\hline & $\mathrm{n}$ & 81 & & 70 & \multicolumn{2}{|c|}{151} \\
\hline \multicolumn{7}{|c|}{$\begin{array}{l}\text { a Perception of financial statement reliability is a variable that is measured by two components: 1) } \\
\text { Intentional misstatement and 2) Unintentional misstatement. This variable is measured on an 11- } \\
\text { point Likert scale anchored at "0" for No Confidence and "10" for Extreme Confidence. } \\
\text { b Sig. stands for significance and all p-values are one-tailed. }\end{array}$} \\
\hline
\end{tabular}


TABLE 3

EFFECTS OF SOURCING AND LOCATION ON PERCEPTIONS OF FINANCIAL STATEMENT RELIABILITY- UNINTENTIONAL MATERIAL MISSTATEMENT ${ }^{A}$

\begin{tabular}{|c|c|c|c|c|c|}
\hline \multicolumn{6}{|c|}{$\begin{array}{l}\text { Panel A: Analysis of Variance for Perceptions of Financial Statement Reliability- } \\
\text { Unintentional Material Misstatement }\end{array}$} \\
\hline$\underline{\text { Source }}$ & $\begin{array}{l}\text { Sum of } \\
\text { Squares }\end{array}$ & $\underline{\mathrm{df}}$ & $\begin{array}{l}\text { Mean } \\
\underline{\text { Square }}\end{array}$ & $\underline{F}$ & $\underline{\text { Sig }}^{b}$. \\
\hline Sourcing & 2.126 & 1 & 2.126 & .379 & .539 \\
\hline Location & .012 & 1 & .012 & .002 & .963 \\
\hline Sourcing * Location & 1.138 & 1 & 1.138 & .203 & .653 \\
\hline Error & 823.783 & 147 & 5.604 & & \\
\hline
\end{tabular}

\begin{tabular}{|c|c|c|c|c|}
\hline \multicolumn{5}{|c|}{$\begin{array}{l}\text { Panel B: Descriptive Statistics (Mean, Standard Deviation, and N) for Reliability- } \\
\text { Unintentional Material Misstatement }\end{array}$} \\
\hline \multirow{3}{*}{ Insource } & & Onshore & Offshore & Total \\
\hline & Mean & 6.3 & 6.20 & 6.31 \\
\hline & $\mathrm{SD}$ & 2.30 & 2.51 & 2.34 \\
\hline \multirow{3}{*}{ Outsource } & $\mathrm{n}$ & 40 & 32 & 72 \\
\hline & Mean & 6.44 & 6.63 & 6.53 \\
\hline & $\mathrm{SD}$ & 2.51 & 2.15 & 2.33 \\
\hline \multirow{4}{*}{ Total } & $\mathrm{n}$ & 41 & 38 & 79 \\
\hline & Mean & 6.41 & 6.44 & 6.42 \\
\hline & SD & 2.39 & 2.31 & 2.34 \\
\hline & $\mathrm{n}$ & 81 & 70 & 151 \\
\hline \multicolumn{5}{|c|}{$\begin{array}{l}\text { a Perceptions of financial statement reliability is a variable that is measured by two } \\
\text { components: 1) Intentional misstatement and 2) Unintentional misstatement. This variable } \\
\text { is measured on an } 11 \text { - point Likert scale anchored at " } 0 \text { " for No Confidence and " } 10 \text { " for } \\
\text { Extreme Confidence. } \\
\text { b Sig. stands for significance and all p-values are one-tailed. }\end{array}$} \\
\hline
\end{tabular}

Panel A of Table 4 shows the Chi-Square results on the bank loan officers decision to either approve or reject the loan. As shown in Panel A of Table 4, the approval rate decreases as the audit procedures move further away from the main auditor (Insource Onshore $-65.0 \%$, Insource Offshore 62.5\%, Outsource Onshore $61.0 \%$ and Outsource Offshore is $60.5 \%)$. However, the Chi-Square results $\left(\mathrm{X}^{2}=\right.$ $.206, \mathrm{p}=.977$ two-tailed) indicate that the difference among the group is not statistically significant. The results imply that the participants in the different treatment groups do not differ in their decisions to either approve or reject the loan. 
TABLE 4

EFFECTS OF SOURCING AND LOCATION ON LOAN DECISIONS

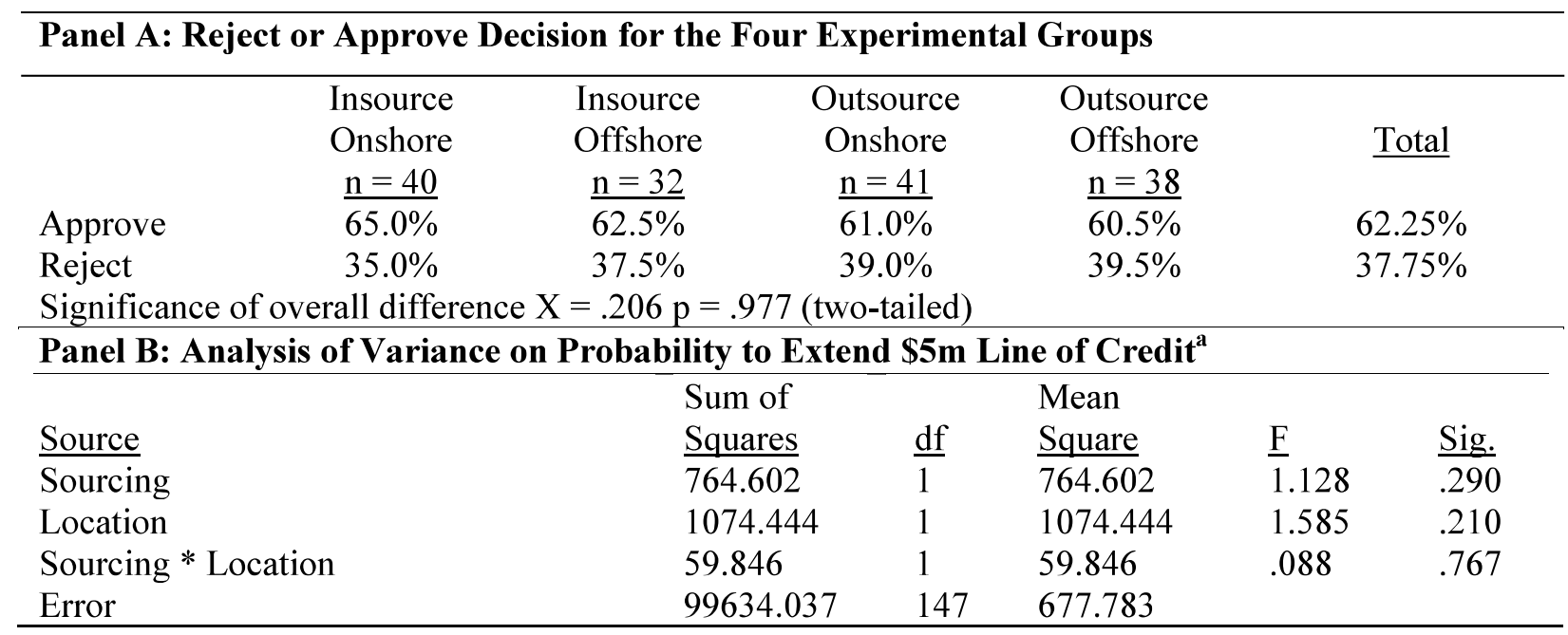

Panel C: Descriptive Statistics- Mean, Standard Deviation (SD) and Sample Size (n) for Probability to Extend Line of Credit

\begin{tabular}{lcccc}
\hline \multirow{2}{*}{ Insource } & Onshore & Offshore & Total \\
& Mean & $42.75 \%$ & $49.38 \%$ & $45.69 \%$ \\
Outsource & $\mathrm{SD}$ & 26.70 & 26.14 & 26.48 \\
& $\mathrm{n}$ & 40 & 32 & 72 \\
Total & $\mathrm{Mean}$ & $48.54 \%$ & $52.63 \%$ & $50.51 \%$ \\
& $\mathrm{SD}$ & 27.71 & 23.21 & 25.57 \\
& $\mathrm{n}$ & 41 & 38 & 79 \\
& $\mathrm{SD}$ & $27.68 \%$ & $51.14 \%$ & 26.03 \\
& $\mathrm{n}$ & 81 & 24.47 & 151 \\
\hline
\end{tabular}

Panel B and C of Table 4 show ANOVA results of the bank loan officers' probability to extend the line of credit at a reasonable interest. Panel $\mathrm{C}$ shows the mean probability for the four experimental groups while Panel B shows the ANOVA results with probability to lend as the dependent variable. The result indicates that the main effects for sourcing $\left(\mathrm{F}_{(1,147)}=1.128, \mathrm{p}=.406\right.$ one-tailed) and location $\left(\mathrm{F}_{(1,}\right.$ ${ }_{147)}=1.585, \mathrm{p}=.210$ one-tailed) are not statistically significant. The interaction between sourcing and location $(\mathrm{F}=.088, \mathrm{p}=.767)$ is also not statistically significant. The results in Table 4 indicate that the bank loan officers in this study do not perceive outsourcing and offshoring audit procedures to impact their loan decisions to clients significantly. 


\section{CONCLUSIONS, LIMITATIONS, AND FUTURE RESEARCH}

Given increased competition and globalization, CPA firms are outsourcing and offshoring audit procedures as a cost reduction strategy. The volume of work outsourced and offshored is expected to increase, but it has been unclear what third parties perceptions are concerning these procedures (Daugherty et al. 2012). Similar to Lyubimov et al. (2013), this study investigates whether sourcing (insourcing versus outsourcing) and location (onshore versus offshore) of audit procedures affect bank loan officers' perceptions of financial statement reliability and loan decisions. The results suggest that bank loan officers' perceptions of financial statement reliability and loan decisions do not differ significantly whether an auditor of another firm or an auditor of the same firm performs the audit procedures. Also, the location (onshored or offshored) of the audit procedures does not significantly affect bank loan officers' perceptions of financial statement reliability and loan decisions.

The results of this study have implications for accounting research, practitioners and policy setters. First, this study contributes to the literature on outsourcing and offshoring independent audit task by providing bank loan officer's perceptions and decisions concerning source and location of audit procedures. Second, the results are important for management on their decisions to engage with a CPA firm that may outsource and offshore the independent audit procedures. Third, this study provides empirical evidence that the sourcing and location of audit procedures do not affect bank loan officers' perceptions and decisions. There are other factors impact bank loan officers' decisions. A study by Bamber and Stratton (1997) shows that the type of audit report whether unqualified or modified affect bank loan officer's decision.

This study is subject to the same limitations that apply to any experimental and survey studies. The data provided to participants may not contain all the information needed for the actual loan process. Similar to Lyubimov et al. (2013), another limitation of this study is that the percentage of the audit procedures performed by the lead auditor and the other auditors are not defined. The participants interpret the meaning of majority. Future studies may specify the percentage of the audit procedures that are sourced to various locations.

The location compared in this study is the U.S. versus India. Future studies can compare bank loan officers' perceptions when the work is offshored to a different country. This study examined bank loan officers' perceptions; future studies can explore other stakeholders' (e.g., investors, managers, the board of directors) perceptions on outsourcing and offshoring audit procedures.

\section{REFERENCES}

Andrews, D., Nonnecke, B., \& Preece, J. (2003). Electronic survey methodology: A case study in reaching hard-to-involve internet users. International Journal of Human- Computer Interaction, 16(2), 185-210.

Baik, B., Kang, J., \& Kim, J. (2010). Local institutional investors, information asymmetries, and equity returns. Journal of Financial Economics, 97(1), 81-106.

Bamber, E. M., \& Stratton, R. A. (1997). The information content of the uncertainty-modified audit report: Evidence from bank loan officers. Accounting Horizons, 11(2), 1-11.

Blackman, A. B., Freedman, M., \& Levy, J. (2004). Outsourcing by CPAs: Are we a business or a profession. The CPA Journal, May, 6-8.

Blinder, A. S. (2006). Offshoring: The next industrial revolution. Foreign Affairs, 85(2), 113-128.

Brandon, D. M., Long, J. H., Loraas, T. M., Mueller-Phillips, J., \& Vansant, B. (2014). Online instrument delivery and participant recruitment services: Emerging opportunities for behavioral accounting research. Behavioral Research in Accounting, 26(1), 1-23. http://doi.org/10.2308/bria-50651

Brody, R. G., Coulter, J. M., \& Jewell, J. (2006). Losing the publics trust : Third-party service providers and disclosure. The CPA Journal, (September), 66-71. 
Brown-Liburd, H., \& Zamora, V. L. (2015). The role of corporate social responsibility (CSR) assurance in investors' judgements when managerial pay is explicitly tied to CSR performance. Auditing: A Journal of Practice \& Theory, 34(1), 75-96.

Bunyaratavej, K., Doh, J., Hahn, E. D., Lewin, A. Y., \& Massini, S. (2011). Conceptual issues in services offshoring research: A multidisciplinary review. Group \& Organization Management, 36(1), 70 102.

Chan, E. W., \& Moser, D. V. (2014). Client management's perceptions of audit offshoring and their willingness to trade off audit quality. Electronic copy available at: http://ssrn.com/abstract $=2156471$.

Choi, J. H., Kim, J. B., Qiu, A., \& Zang, Y. (2012). Geographic proximity between auditor and client: How does it impact audit quality? Auditing: A Journal of Practice \& Theory, 31(2), 43-72. http://doi.org/10.2308/ajpt-10241

Daugherty, B., Dickins, D., \& Fennema, M. G. (2013). The effects of offshoring audit tasks on jurors evaluations of damage awards against auditors. Advances in Accounting Behavioral Research, 16, $55-84$.

Daugherty, B. E., \& Dickins, D. (2009). Offshoríng the independent audit function: Consideration, implications and research opportunities. The CPA Journal, (January), 60-66.

Daugherty, B. E., Dickins, D., \& Fennema, M. G. (2012). Offshoring tax and audit procedures: Implications for U.S.-based employee education. Issues in Accounting Education, 27(3), $733-$ 742. http://doi.org/10.2308/iace-50141

Downey, D. H. (2017). An Exploration of Offshoring in Audit Practice and the Potential Consequences of Associated Work "Re-Design" on Auditor Performance. Auditing: A Journal of Practice \& Theory. http://doi.org/10.2308/accr-50982

Dutta, A., \& Roy, R. (2005). Offshore outsourcing: A dynamic causal model of counteracting forces. Journal of Information Systems, 22(2), 15-35.

Foster, B. P., Mcclain, G., \& Shastri, T. (2013). The auditor's report on internal control \& fraud detection responsibility: A comparison of French and U.S. users' perceptions. Journal of Accounting, Ethics, \& Public Policy, 14(2), 221-257.

Garner, A. C. (2004). Offshoring in the service sector: Economic impact and policy issues. Economic Review-Federal Reserve Bank of Kansas City, 89(3), 5-37.

Gião, P. R., Oliveira Junior, M., \& Gondim de Vasconcellos, E. (2008). Services offshoring and its strategic effects on value chains. Brazilian Administration Review, 5(3), 193-209.

Grappi, S., Romani, S., \& Bagozzi, R. P. (2013). The effects of company offshoring strategies on consumer responses. Journal of the Academy of Marketing Science, 41(6), 683-704. http://doi.org/10.1007/s11747-013-0340-y

Hanes, D. R. (2013). Geographically distributed audit work: Theoretical considerations and future directions. Journal of Accounting Literature, 32(1), 1-29. http://doi.org/10.1016/j.acclit.2013.09.001

Kedia, S., \& Rajgopal, S. (2011). Do the SEC's enforcement preferences affect corporate misconduct? Journal of Accounting and Economics, 51(3), 259-279.

Li, S., Qiu, J., \& Wan, C. (2011). Corporate globalization and bank lending. Journal of International Business Studies, 42(8), 1016-1042. Retrieved from http://www.jstor.org/stable/41309746 .

Lowe, D. J., Geiger, M. A., \& Pany, K. (1999). The effects of internal audit outsourcing on perceived external auditor independence. Auditing: A Journal of Practice \& Theory, 18(Supplement), 7-26.

Lyubimov, A., Arnold, V., \& Sutton, S. G. (2013). An examination of the legal liability associated with outsourcing and offshoring audit procedures. Auditing: A Journal of Practice \& Theory, 32(2), 97-118. http://doi.org/10.2308/ajpt-50354

Malloy, C. (2005). The geography of equity analysis. The Journal of Finance, 60(2), 719-756.

Massini, S., \& Miozzo, M. (2012). Outsourcing and offshoring of business services : Challenges to theory , management and geography of innovation. Regional Studies, 46(October), 1219-1242.

Mintz, S. (2004). The ethical dilemmas of outsourcing. The CPA Journal, 74(3), 6-10. 
Oppenheimer, D. M., Meyvis, T., \& Davidenko, N. (2009). Instructional manipulation checks: Detecting satisficing to increase statistical power. Journal of Experimental Social Psychology, 45, 867-872.

Polzer, J. T., Crisp, C. ., Jarvenpaa, S. L., \& Kim, J. . (2006). Extending the faultline model to geographically dispersed teams: How collocated subgroups can impair group functioning. The Academy of Management Journal, 49(4), 679-692.

Public Company Accounting Oversight Board, (PCAOB). (2011). Improving the transparency of audit: Proposed amendments to PCAOB auditing standards and form 2. PCAOB Release No. 2011-007. Washington D.C.

Public Company Accounting Oversight Board, (PCAOB). (2017). The Auditor's Report on an Audit of Financial Statements When the Auditor Expresses an Unqualified Opinion ,. PCAOB Rulemaking Docket Matter No.034. Washington D.C.

Robertson, C. J., Lamin, A., \& Livanis, G. (2010). Stakeholders perceptions of offshoring and outsourcing: The role of embedded issues. Journal of Business Ethics, 95, 167-189.

Robertson, C. J., \& Stone, D. (2005). Offshore outsourcing of tax return preparation. The CPA Journal, 75(June), 55-58.

Roth, K., \& O'Donnell, S. (1996). Foreign subsidiary compensation: An agency theory perspective. Academy of Management Journal, 39(3), 678-703.

Schneider, A., \& Church, B. K. (2008). The effect of auditors' internal control opinions on loan decisions. Journal of Accounting and Public Policy, 27(1), 1-18.

Selvaggio, L. (2014). Outsourcing Statistics-pros and cons. Retrieved October 2, 2017, from https://blog.udemy.com/OUTSOURCING-STATISTICS

Shamis, G. S., Green, M. C., Sorensen, S. M., \& Kyle, D. L. (2005). Outsourcing, offshoring, nearshoring: What to Do ? Journal of Accountancy, (June), 57-61.

Smith, J. L. (2012). Investors' perceptions of audit Quality: Effects of regulatory change. Auditing: A Journal of Practice \& Theory, 31(1), 17-38. http://doi.org/10.2308/ajpt-10192

Sunderland, D., \& Trompeter, G. M. (2017). Multinational Group Audits: Problems Faced in Practice and Opportunities for Research. AUDITING: A JOURNAL OF PRACTICE \& THEORY American Accounting Association, 36(3), 159-183. http://doi.org/10.2308/ajpt-51667

Swanger, S. L., \& Chewning, E. G. (2001). The effect of internal audit outsourcing on financial analysts' perceptions of external auditor independence. Auditing: A Journal of Practice \& Theory, 20(2), 115-129. http://doi.org/10.2308/aud.2001.20.2.115

Whitehouse, T. (2009). Offshored external audits expose regulatory issues. Compliance Week, April, 2680. 


\title{
INSTRUMENT
}

\author{
Instruction and Consent Form \\ Prescreening Question
}

Do you have at least one year lending experience?

Y Yes (1)

No (2)

\section{Part1-Case I}

\section{Part 1}

Introduction

Please assume that you are being asked to evaluate a line of credit application from a fictitious company, Chad Widget Company to support a strategic marketing campaign. Chad Widget Company sells widgets and is a new customer for your bank, with no prior history of credit relationship with your bank. The information presented in this case is not intended to be comprehensive or representative of what would normally be available when you evaluate a company. Please base your judgment about Chad Widget Company only on the information provided in the case. Presented below is the background information of the company

\section{Chad Widget Company Background Information}

Chad Widget Company, a publicly-traded company, has experienced steady growth since operations began in 1996. Revenues have increased an average of $8 \%$ per year for the past four years and, according to the CFO, they are expected to increase by $12 \%$ during the next year.

The company is seeking to obtain a $\$ 5,000,000$ line of credit for the next year from your financial institution because it is planning an aggressive marketing campaign. The line of credit would be secured by the company's accounts receivable. Chad Widget Company does not currently have a business relationship with your financial institution. To facilitate your analysis, financial statements are also presented. These financial statements were audited by Zodak CPA, an international accounting firm with headquarters located in the USA and received a clean (i.e., unqualified) opinion.

You learned that for the 2014 audit of Chad Widget Company (which took place in February and March of 2015), Zodak CPA disclosed that they used their own local office personnel to complete the majority of the work, but also engaged another office of their own firm located in Texas to perform certain revenue audit procedures required in the audit of Chad Widget Company. Zodak CPA has sent work to this office several times over the past two years and has not had any problems.

Zodak CPA also states that they are responsible for the audit procedures performed by the auditors in the other office of Zodak firm in Texas and accordingly have supervised its work in accordance with PCAOB standards. 


\begin{tabular}{|c|c|c|c|}
\hline \multicolumn{2}{|c|}{$\begin{array}{l}\text { CHAD WIDGET COMPANY } \\
\text { BALANCE SHEET } \\
\text { AS OF JUNE 30, } 2014\end{array}$} & \multicolumn{2}{|c|}{$\begin{array}{c}\text { CHAD WIDGET COMPANY } \\
\text { STATEMENT OF INCOME AND RETAINED } \\
\text { EARNINGS } \\
\text { FOR THE YEAR ENDED JUNE 30, } 2014\end{array}$} \\
\hline \multicolumn{4}{|l|}{ Assets } \\
\hline Current Assets & & Sales & $\$ 432,000,000$ \\
\hline Cash & $\$ 12,496,000$ & Cost of Goods Sold & $342,400,000$ \\
\hline Accounts Receivable, Net & $31,072,000$ & Gross Margin & $\$ 89,600,000$ \\
\hline Inventories & $50,208,000$ & Operating Expense & $82,000,000$ \\
\hline Total Current Assets & $\$ 93,776,000$ & Income from Operations & $\$ 7,600,000$ \\
\hline Fixed Assets, net & $40,736,000$ & Interest Expense & $3,860,000$ \\
\hline Total Assets & $\overline{\$ 134.512 .0000}$ & $\begin{array}{l}\text { Income Before Taxes } \\
\text { Income Tax Expenses }\end{array}$ & $\begin{array}{ll}S 3,740,000 \\
1,010,000 \\
\end{array}$ \\
\hline \multicolumn{2}{|l|}{ Equity } & Net Income & $S \quad 2,730,000$ \\
\hline Current Liabilities: & & Retained Earnings at Beginning of year & $5,182,000$ \\
\hline Notes Payable & $\$ 16,448,000$ & Retained earnings at End of Year & $\$ 7,912,000$ \\
\hline Accounts Payable & $30,512,000$ & & \\
\hline Income Taxes Payable & 784,000 & Earnings Per Share & 0.27 \\
\hline Total Current Liabilities & $\overline{\$ 47,744,000}$ & & \\
\hline Long -Term Notes Payable & $\$ 30,840,000$ & & \\
\hline \multirow[t]{2}{*}{ Total Liabilities } & $\$ 78,584,000$ & & \\
\hline & & $\begin{array}{r}\text { CHAD WIDGET COI } \\
\text { STATEMENT OF CAS } \\
\text { FOR THE YEAR ENDED J }\end{array}$ & $\begin{array}{l}\text { WY } \\
\text { 30, } 2014\end{array}$ \\
\hline Capital & $\$ 48,016,000$ & Cash Flows from Operating Activities & \\
\hline Retained Earnings & $7,912.000$ & Net Income & $\$ 2,730,000$ \\
\hline \multirow[t]{2}{*}{ Total Owners' Equity } & $\overline{\$ 55,928,000}$ & Net Non-Cash Adjustment & $(2,424,000)$ \\
\hline & & Cash provided from operation & $\$ 3306,000$ \\
\hline \multirow{3}{*}{$\begin{array}{l}\text { Total Liabilities and Owners' } \\
\text { Equity }\end{array}$} & $\$ 134.512 .000$ & Cash Flows From Investing Activities & $(\$ 5,544,000)$ \\
\hline & & Cash Flows From Financing Activities & $(\$ 2,736,000)$ \\
\hline & & Net Decrease in Cash & (S 7,974,000) \\
\hline
\end{tabular}

Based on the information provided, please answer the following questions on Chad Widget Company. Assume that your financial institution does not restrict you on the size of the loan that you may grant and that your institution is not limited in the amount of fund that it has available to lend. To answer a question, please click on the section of the scale that corresponds to your desired response. 


\section{Part 1-Case 2}

\section{Introduction}

Please assume that you are being asked to evaluate a line of credit application from a fictitious company, Chad Widget Company to support a strategic marketing campaign. Chad Widget Company sells widgets and is a new customer for your bank, with no prior history of credit relationship with your bank. The information presented in this case is not intended to be comprehensive or representative of what would normally be available when you evaluate a company. Please base your judgment about Chad Widget Company only on the information provided in the case. Presented below is the background information of the company

\section{Chad Widget Company Background Information}

Chad Widget Company, a publicly-traded company, has experienced steady growth since operations began in 1996. Revenues have increased an average of $8 \%$ per year for the past four years and, according to the CFO, they are expected to increase by $12 \%$ during the next year.

The company is seeking to obtain a $\$ 5,000,000$ line of credit for the next year from your financial institution because it is planning an aggressive marketing campaign. The line of credit would be secured by the company's accounts receivable. Chad Widget Company does not currently have a business relationship with your financial institution. To facilitate your analysis, financial statements are also presented. These financial statements were audited by Zodak CPA, an international accounting firm with headquarters located in the USA and received a clean (i.e., unqualified) opinion.

You learned that For the 2014 audit of Chad Widget Company (which took place in February and March of 2015), Zodak CPA disclosed that they used their own local office personnel to complete the majority of the work, but also engaged another office of their own firm located in India to perform certain revenue audit procedures required in the audit of Chad Widget Company. Zodak CPA has sent work to this office several times over the past two years and has not had any problems.

Zodak CPA also states that they are responsible for the audit procedures performed by the auditors in the other office of Zodak firm in India and accordingly have supervised its work in accordance with PCAOB standards. 


\begin{tabular}{|c|c|c|c|}
\hline \multicolumn{2}{|c|}{$\begin{array}{l}\text { CHAD WIDGET COMPANY } \\
\text { BALANCE SHEET } \\
\text { AS OF JUNE 30, } 2014\end{array}$} & \multicolumn{2}{|c|}{$\begin{array}{c}\text { CHAD WIDGET COMPANY } \\
\text { STATEMENT OF INCOME AND RETAINED } \\
\text { EARNINGS } \\
\text { FOR THE YEAR ENDED JUNE 30, } 2014\end{array}$} \\
\hline \multicolumn{4}{|l|}{ Assets } \\
\hline Current Assets & & Sales & $\$ 432,000,000$ \\
\hline Cash & $\$ 12,496,000$ & Cost of Goods Sold & $342,400,000$ \\
\hline Accounts Receivable, Net & $31,072,000$ & Gross Margin & $\$ \overline{89,600,000}$ \\
\hline Inventories & $50,208,000$ & Operating Expense & $82,000,000$ \\
\hline Total Current Assets & $\$ 93,776,000$ & Income from Operations & $\$ 7,600,000$ \\
\hline Fixed Assets, net & $40,736,000$ & Interest Expense & $3,860,000$ \\
\hline Total Assets & $\$ \mathbf{\$ 1 3 4 . 5 1 2 . 0 0 0}$ & $\begin{array}{l}\text { Income Before Taxes } \\
\text { Income Tax Expenses }\end{array}$ & $\begin{array}{ll}S \quad 3,740,000 \\
\quad 1,010,000 \\
\end{array}$ \\
\hline \multicolumn{2}{|l|}{ Equity } & Net Income & S $2,730,000$ \\
\hline Current Liabilities: & & Retained Earnings at Beginning of year & $5,182,000$ \\
\hline Notes Payable & $\$ 16,448,000$ & Retained earnings at End of Year & $\$ \quad 7,912,000$ \\
\hline Accounts Payable & $30,512,000$ & & \\
\hline Income Taxes Payable & 784.000 & Earnings Per Share & 0.27 \\
\hline Total Current Liabilities & $\overline{\$ 47,744,000}$ & & \\
\hline Long -Term Notes Payable & $\$ 30,840,000$ & & \\
\hline \multirow[t]{2}{*}{ Total Liabilities } & 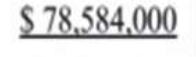 & & \\
\hline & & \multicolumn{2}{|c|}{$\begin{array}{c}\text { CHAD WIDGET COMPANY } \\
\text { STATEMENT OF CASH FLOWS } \\
\text { FOR THE YEAR ENDED JUNE 30, } 2014\end{array}$} \\
\hline \multicolumn{4}{|l|}{ Owners' Equity: } \\
\hline Retained Earnings & $\begin{array}{r}7,912,000 \\
\end{array}$ & Net Income & S $2,730,000$ \\
\hline \multirow[t]{2}{*}{ Total Owners' Equity } & $\$ \$ 55,928,000$ & Net Non-Cash Adjustment & $(2,424,000)$ \\
\hline & & Cash provided from operation & $S \longdiv { 3 0 6 , 0 0 0 }$ \\
\hline \multirow{3}{*}{$\begin{array}{l}\text { Total Liabilities and Owners' } \\
\text { Equity }\end{array}$} & $\$ 134.512 .000$ & Cash Flows From Investing Activities & $(\$ 5,544,000)$ \\
\hline & & Cash Flows From Financing Activities & $(\$ 2,736,000)$ \\
\hline & & Net Decrease in Cash & (S 7,974,000) \\
\hline
\end{tabular}

Based on the information provided, please answer the following questions on Chad Widget Company. Assume that your financial institution does not restrict you on the size of the loan that you may grant and that your institution is not limited in the amount of fund that it has available to lend. To answer a question, please click on the section of the scale that corresponds to your desired response. 


\section{Part1-Case 3}

\section{Introduction}

Please assume that you are being asked to evaluate a line of credit application from a fictitious company, Chad Widget Company to support a strategic marketing campaign. Chad Widget Company sells widgets and is a new customer for your bank, with no prior history of credit relationship with your bank. The information presented in this case is not intended to be comprehensive or representative of what would normally be available when you evaluate a company. Please base your judgment about Chad Widget Company only on the information provided in the case. Presented below is the background information of the company.

\section{Chad Widget Company Background Information}

Chad Widget Company, a publicly-traded company, has experienced steady growth since operations began in 1996. Revenues have increased an average of $8 \%$ per year for the past four years and, according to the CFO, they are expected to increase by $12 \%$ during the next year. The company is seeking to obtain a $\$ 5,000,000$ line of credit for the next year from your financial institution because it is planning an aggressive marketing campaign. The line of credit would be secured by the company's accounts receivable. Chad Widget Company does not currently have a business relationship with your financial institution. To facilitate your analysis, financial statements are also presented. These financial statements were audited by Zodak CPA, an international accounting firm with headquarters located in the USA and received a clean (i.e., unqualified) opinion.

You learned that for the 2014 audit of Chad Widget Company (which took place in February and March of 2015), Zodak CPA disclosed that they used their own local office personnel to complete the majority of the work, but also engaged another accounting firm located in Texas (a different firm) to perform certain revenue audit procedures required in the audit of Chad Widget Company. Zodak CPA has sent work to this office several times over the past two years and has not had any problems.

Zodak CPA also states that they are responsible for the audit procedures performed by the auditors in the other accounting firm in Texas and accordingly have supervised its work in accordance with PCAOB standards. 


\begin{tabular}{|c|c|c|c|}
\hline \multicolumn{2}{|c|}{$\begin{array}{l}\text { CHAD WIDGET COMPANY } \\
\text { BALANCE SHEET } \\
\text { AS OF JUNE 30, } 2014\end{array}$} & \multicolumn{2}{|c|}{$\begin{array}{c}\text { CHAD WIDGET COMPANY } \\
\text { STATEMENT OF INCOME AND RETAINED } \\
\text { EARNINGS } \\
\text { FOR THE YEAR ENDED JUNE 30, } 2014\end{array}$} \\
\hline \multicolumn{4}{|l|}{ Assets } \\
\hline Current Assets & & Sales & $\$ 432,000,000$ \\
\hline Cash & $\$ 12,496,000$ & Cost of Goods Sold & $342,400,000$ \\
\hline Accounts Receivable, Net & $31,072,000$ & Gross Margin & $\$ \overline{89,600,000}$ \\
\hline Inventories & $50,208,000$ & Operating Expense & $82,000,000$ \\
\hline Total Current Assets & $\$ 93,776,000$ & Income from Operations & $\$ 7,600,000$ \\
\hline Fixed Assets, net & $40,736,000$ & Interest Expense & $3,860,000$ \\
\hline Total Assets & $\$ \mathbf{\$ 1 3 4 . 5 1 2 . 0 0 0}$ & $\begin{array}{l}\text { Income Before Taxes } \\
\text { Income Tax Expenses }\end{array}$ & $\begin{array}{ll}S \quad 3,740,000 \\
\quad 1,010,000 \\
\end{array}$ \\
\hline \multicolumn{2}{|l|}{ Equity } & Net Income & S $2,730,000$ \\
\hline Current Liabilities: & & Retained Earnings at Beginning of year & $5,182,000$ \\
\hline Notes Payable & $\$ 16,448,000$ & Retained earnings at End of Year & $\$ \quad 7,912,000$ \\
\hline Accounts Payable & $30,512,000$ & & \\
\hline Income Taxes Payable & 784.000 & Earnings Per Share & 0.27 \\
\hline Total Current Liabilities & $\overline{\$ 47,744,000}$ & & \\
\hline Long -Term Notes Payable & $\$ 30,840,000$ & & \\
\hline \multirow[t]{2}{*}{ Total Liabilities } & 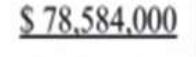 & & \\
\hline & & \multicolumn{2}{|c|}{$\begin{array}{c}\text { CHAD WIDGET COMPANY } \\
\text { STATEMENT OF CASH FLOWS } \\
\text { FOR THE YEAR ENDED JUNE 30, } 2014\end{array}$} \\
\hline \multicolumn{4}{|l|}{ Owners' Equity: } \\
\hline Retained Earnings & $\begin{array}{r}7,912,000 \\
\end{array}$ & Net Income & S $2,730,000$ \\
\hline \multirow[t]{2}{*}{ Total Owners' Equity } & $\$ \$ 55,928,000$ & Net Non-Cash Adjustment & $(2,424,000)$ \\
\hline & & Cash provided from operation & $S \longdiv { 3 0 6 , 0 0 0 }$ \\
\hline \multirow{3}{*}{$\begin{array}{l}\text { Total Liabilities and Owners' } \\
\text { Equity }\end{array}$} & $\$ 134.512 .000$ & Cash Flows From Investing Activities & $(\$ 5,544,000)$ \\
\hline & & Cash Flows From Financing Activities & $(\$ 2,736,000)$ \\
\hline & & Net Decrease in Cash & (S 7,974,000) \\
\hline
\end{tabular}

Based on the information provided, please answer the following questions on Chad Widget Company. Assume that your financial institution does not restrict you on the size of the loan that you may grant and that your institution is not limited in the amount of fund that it has available to lend. To answer a question, please click on the section of the scale that corresponds to your desired response. 


\section{Part1 -Case 4}

\section{Introduction}

Please assume that you are being asked to evaluate a line of credit application from a fictitious company, Chad Widget Company to support a strategic marketing campaign. Chad Widget Company sells widgets and is a new customer for your bank, with no prior history of credit relationship with your bank. The information presented in this case is not intended to be comprehensive or representative of what would normally be available when you evaluate a company. Please base your judgment about Chad Widget Company only on the information provided in the case. Presented below is the background information of the company.

\section{Chad Widget Company Background Information}

Chad Widget Company, a publicly-traded company, has experienced steady growth since operations began in 1996. Revenues have increased an average of $8 \%$ per year for the past four years and, according to the CFO, they are expected to increase by $12 \%$ during the next year. The company is seeking to obtain a $\$ 5,000,000$ line of credit for the next year from your financial institution because it is planning an aggressive marketing campaign. The line of credit would be secured by the company's accounts receivable. Chad Widget Company does not currently have a business relationship with your financial institution. To facilitate your analysis, financial statements are also presented. These financial statements were audited by Zodak CPA, an international accounting firm with headquarters in the USA and received a clean (i.e., unqualified) opinion.

You learned that for the 2014 audit of Chad Widget Company (which took place in February and March of 2015), Zodak CPA disclosed that they used their own local office personnel to complete the majority of the work, but also engaged another accounting firm located in India (a different firm) to perform certain revenue audit procedures required in the audit of Chad Widget Company. Zodak CPA has sent work to this office several times over the past two years and has not had any problems.

Zodak CPA also states that they are responsible for the audit procedures performed by the auditors in the other accounting firm in India and accordingly have supervised its work in accordance with PCAOB standards. 


\begin{tabular}{|c|c|c|c|}
\hline \multicolumn{2}{|c|}{$\begin{array}{l}\text { CHAD WIDGET COMPANY } \\
\text { BALANCE SHEET } \\
\text { AS OF JUNE 30, } 2014\end{array}$} & \multicolumn{2}{|c|}{$\begin{array}{c}\text { CHAD WIDGET COMPANY } \\
\text { STATEMENT OF INCOME AND RETAINED } \\
\text { EARNINGS } \\
\text { FOR THE YEAR ENDED JUNE 30, } 2014\end{array}$} \\
\hline \multicolumn{4}{|l|}{ Assets } \\
\hline Current Assets & & Sales & $\$ 432,000,000$ \\
\hline Cash & $\$ 12,496,000$ & Cost of Goods Sold & $342,400,000$ \\
\hline Accounts Receivable, Net & $31,072,000$ & Gross Margin & $\$ \overline{89,600,000}$ \\
\hline Inventories & $50,208,000$ & Operating Expense & $82,000,000$ \\
\hline Total Current Assets & $\$ 93,776,000$ & Income from Operations & $\$ 7,600,000$ \\
\hline Fixed Assets, net & $40,736,000$ & Interest Expense & $3,860,000$ \\
\hline Total Assets & $\$ \mathbf{\$ 1 3 4 . 5 1 2 . 0 0 0}$ & $\begin{array}{l}\text { Income Before Taxes } \\
\text { Income Tax Expenses }\end{array}$ & $\begin{array}{ll}S \quad 3,740,000 \\
\quad 1,010,000 \\
\end{array}$ \\
\hline \multicolumn{2}{|l|}{ Equity } & Net Income & S $2,730,000$ \\
\hline Current Liabilities: & & Retained Earnings at Beginning of year & $5,182,000$ \\
\hline Notes Payable & $\$ 16,448,000$ & Retained earnings at End of Year & $\$ \quad 7,912,000$ \\
\hline Accounts Payable & $30,512,000$ & & \\
\hline Income Taxes Payable & 784.000 & Earnings Per Share & 0.27 \\
\hline Total Current Liabilities & $\overline{\$ 47,744,000}$ & & \\
\hline Long -Term Notes Payable & $\$ 30,840,000$ & & \\
\hline \multirow[t]{2}{*}{ Total Liabilities } & 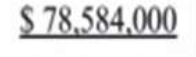 & & \\
\hline & & \multicolumn{2}{|c|}{$\begin{array}{c}\text { CHAD WIDGET COMPANY } \\
\text { STATEMENT OF CASH FLOWS } \\
\text { FOR THE YEAR ENDED JUNE 30, } 2014\end{array}$} \\
\hline \multicolumn{4}{|l|}{ Owners' Equity: } \\
\hline Retained Earnings & $\begin{array}{r}7,912,000 \\
\end{array}$ & Net Income & S $2,730,000$ \\
\hline \multirow[t]{2}{*}{ Total Owners' Equity } & $\$ \$ 55,928,000$ & Net Non-Cash Adjustment & $(2,424,000)$ \\
\hline & & Cash provided from operation & $S \longdiv { 3 0 6 , 0 0 0 }$ \\
\hline \multirow{3}{*}{$\begin{array}{l}\text { Total Liabilities and Owners' } \\
\text { Equity }\end{array}$} & $\$ 134.512 .000$ & Cash Flows From Investing Activities & $(\$ 5,544,000)$ \\
\hline & & Cash Flows From Financing Activities & $(\$ 2,736,000)$ \\
\hline & & Net Decrease in Cash & (S 7,974,000) \\
\hline
\end{tabular}

Based on the information provided, please answer the following questions on Chad Widget Company. Assume that your financial institution does not restrict you on the size of the loan that you may grant and that your institution is not limited in the amount of fund that it has available to lend. To answer a question, please click on the section of the scale that corresponds to your desired response. 


\section{Case Questions}

Based on the information provided, please answer the following questions on Chad Widget Company. To answer a question, please click on the section of the scale that corresponds to your desired response.

(a) On a scale of $0-10$, how confident are you that Chad Widget Company's financial statements are free from intentional material misstatement"?

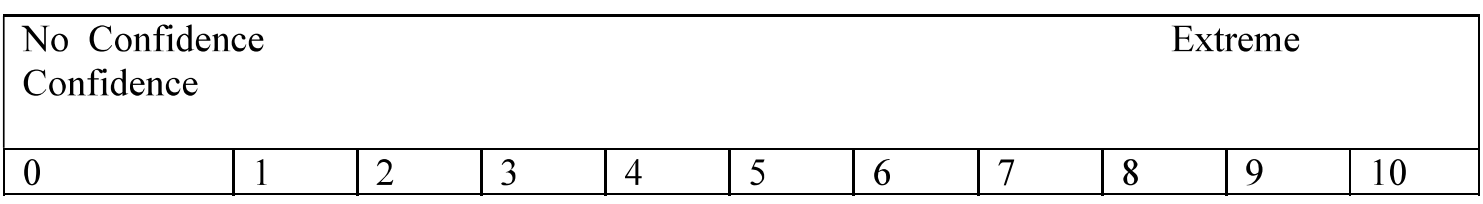

(b) On a scale from 0-10, how confident are you that Chad Widget Company's financial statements are free from unintentional material misstatement?

\begin{tabular}{l|l|l|l|l|l|l|l|l|l|l|}
\hline $\begin{array}{l}\text { No Confidence } \\
\text { Confidence }\end{array}$ \\
\hline 0 & 1 & 2 & 3 & 4 & 5 & 6 & 7 & 8 & 9 & 10 \\
\hline
\end{tabular}

(c) What is the level of risk associated with extending the $\$ 5$ million line of credit to Chad Widget Company?

\begin{tabular}{|l|l|l|l|l|l|l|l|l|l|l|}
\hline Very Low Risk & \multicolumn{1}{c|}{ Very High } \\
Risk \\
\hline 0
\end{tabular}

(d) What recommendation would you make on the loan application?

"Accept" or "Reject"

(e) What is the probability that you would extend the $\$ 5,000,000$ line of credit to Chad Widget Company at a reasonable rate of interest as determined by your financial institution?

\begin{tabular}{|l|l|l|l|l|l|l|l|l|l|l|}
\hline $0 \%$ & $10 \%$ & $20 \%$ & $30 \%$ & $40 \%$ & $50 \%$ & $60 \%$ & $70 \%$ & $80 \%$ & $90 \%$ & $100 \%$ \\
\hline
\end{tabular}

This is the end of Part 1. After you have carefully reviewed the case information and your responses, please continue to Part 2. Please ensure that you have responded to all questions. You may scroll up and down while you are in this section to review the case and questions. You will not be able to return to these questions or review the case after clicking on the forward button. 


\section{Part 2-Manipulation Check}

Please answer the following questions without going back to previous screens.

In the case that you just read, Zodak CPA engaged:

A different firm to perform certain audit procedures

Another office of their own to perform certain audit procedures

In the case that you just read, were parts of the audit performed outside of the United States?

Yes

No

\section{Part 4- Demographic Questions}

1. What is the highest degree earned?

High School Diploma

Associate Degree

Bachelor's Degree

Master's

Doctorate

Other, please specify

2. What is the title of your current position?

Credit Analyst

Loan Officer

Vice President

President/CEO

Other, please specify

3. How many years of professional experience do you have in banking?

4. How many years of lending experience do you have? 
5. What percentage of your time is devoted to making loan decisions?

Below 50\%

$50-69 \%$

$70-79 \%$

$80-89 \%$

Over $90 \%$

6. What is your bank asset size?

Less than $\$ 100$ million

$\$ 100$ million - \$1 billion

Over $\$ 1$ billion - $\$ 10$ billion

Over $\$ 10$ billion

7. Do you have a professional designation?

Yes (please specify)

No

8. What is your gender?

Male

Female

9. How old are you?

Under 26

$26-35$

$36-45$

$46-55$

$56-65$

Over 65 
10. What is your knowledge of auditing?

Not at all knowledgeable

Somewhat knowledgeable

Very knowledgeable

11. What is your knowledge of outsourcing audit procedures (Having employees of another CPA firm perform some or all of the audit procedures)?

Not at all knowledgeable

Somewhat knowledgeable

Very knowledgeable

12. What is your knowledge of offshoring audit procedures? (Having audit procedures performed by a CPA firm's employee or another CPA's firm employee located in a foreign country e.g. India)

Not at all knowledgeable

Somewhat knowledgeable

Very knowledgeable

Thank you for your participation! Please continue to the next page to save your responses. 